They have arranged to meet Prof. Toumey of the University of Arizona, and his party, consisting of men from the Agricultural Department in Washington, who start by wagon from Tucson, at Flagstaff about the first of July. They will then go on to the Grand Cañon together, remaining in company three or four weeks, and returning by way of the eastern boundary of Arizona. The object of both parties is the collection of insects and plants.

Dr. W. J. Holland of Pittsburg sailed for Europe June 29 and during the summer will prosecute some entomological studies in the museums of London and Paris.

\section{BIBLIOGRAPHICAL NOTES. - II.}

BY SAMUEL heNSHAW.

Biologia Centrali-Americana. - Coleoptera. Vol. I. By Henry Walter Bates.

Cicindelidae, I881, pt. ז3-14, p. 1-18; gen. $\mathrm{sp}$ : I 883 , pt. 27 , p. 256 ; 884 , pt. 3 I, p. 257 -26r.

Carabidae, I88I, pt. I4, p. 19.40; I882,

pt. $15-19$, p. $4 \mathrm{I}-15^{2} ; \mathrm{I} 883$, pt. $2 \mathrm{I}$ -

$22,25,27$, p. I $53^{-2} 55 ;$ 1 884 , pt. $3^{1-}$

32,34, p. 26I-299.

I44999

Species of the following genera are figured :-

Cicindelidae. - Cicindela, I, 13. Ctenostoma, I. Odontocheila, 1, I3. Oxycheila, I. Oxygonia, I. Pseudoxycheila, I. Tetracha, I.

Carabidae. - Abaris, 4. Adrimus, 4. Agra, 12. Allotriopus, 4, Amara, 4. Anatrichis, 3. Anchomenus, 4. Ancistroglossus, 7. Anillus, 6. Anisodactylus, 3 . Anisotarsus, 3. Apenes, 7, 8, 13. Apristus, 8. Ardistomis, 2. Arthrostictus, 3. Aspasiola, 8. Aspidoglossa, 2. Axinopalpus, 8. Barysomus, 3. Bembidium, 6. Brachinus, 7. Calathus, 4. Calleida, 9, I3. Calophaena, 6. Calosoma, 2. Carabus, I3. Casnonia, 6, I3. Catapiesis, 4. Catascopus, 7. Celia, 4. Chlaenius, 3, I3. Clivina, 2. Clopodes, 5, r3. Coptodera, 7. Cratocera, 4. Cryptobatis, 8. Curtonotus, 4. ${ }^{*} \mathrm{Cyr}$ - tolaus, 5. Diaphorus, 6, I3 Diploharpus, 6. Discoderus, 3. Dromius, 8. Ega, 6. *Elliptoleus, 4. Euchroa, 4. Euproctus, 8 Eurycoleus, 7. Evarthrus, I4. Galerita, 6, 7. Gallerucidia, 9. Glyptolenus, 5, 13Helluomorpha, 7. Hyboptera, 8. Hypher, pes, 4. *Ithytolus, I3. Lachnophorus, 6. Lebia, IO, II, I2. Lelis, 7. Leptotrachelus 6. Lia, I2. Loricera, 2. Loxandrus, 4, I3 Loxopeza, Io. Menidius, 8. Micragra, 6 *Mioptachys, 6. Mizotrechus, 6. Morio, 4 Moriosomus, 4. Nemotarsus, 7. Notiobia 3, 13. Notiophilus, 2. *Ochropisus, 7 Omophron, 2. Onota, 8, I3. Onyptergyia 5. Otoglossa, 8. Pachyteles, 2, I3. Panagaeus, 3. Pasimachus, 2. Pelecium, 3. *Pelmatellus, 3. Pentagonica, 9. *Per. colaus, 4. Pericompsus, 6, 13. Perigona, 6. Pheropsophus, 7. Philopheuga, 9. Phloeoxena, 7. Physea, 2. Pinacodera, $7,8$. Platynus, 4. Platysoma, 4. Polpochila 3.' Pseudomorpha, I2. Scaphinotus, 13. Schi. zogenius, 2. Selenophorus, 3, 13. Stenocrepis, 3. Stenoglossa, 7. Stenognathus, 7 . Stenomorphus, 3. Stenous, 3. Stolonis, 4. Tachys, 6. Tachyta, 6. Tetragonoderus, 7, Trechus, 6. Xystosomus, 6 .

New genera are marked $(*)$; the figure following the name of the genus denotes the number of the plate. Of the 85 species of Cicindelidae found in Central America 18 species occur in America north of Mexico, and of the 999 species of Carabidae from Central America, 84 are found in America north of Mexico.

Cerura modesta. - In my list of the Bombyces taken at electric light in Poughkeepsie, N. Y., given not long since in Psyche, occurs the name Cerura aquilonaris. This I now believe is an error, and the name should be Cerura modesta Hudson. This species was not then described, and the determination was made from a single example in very poor condition taken from the lamps previous to $1890, C$. aquilonaris Lintn. (=scolopendrina Boisd.) probably does not occur in New York.-HARRISON G. DyaR. 



Submit your manuscripts at

http://www.hindawi.com
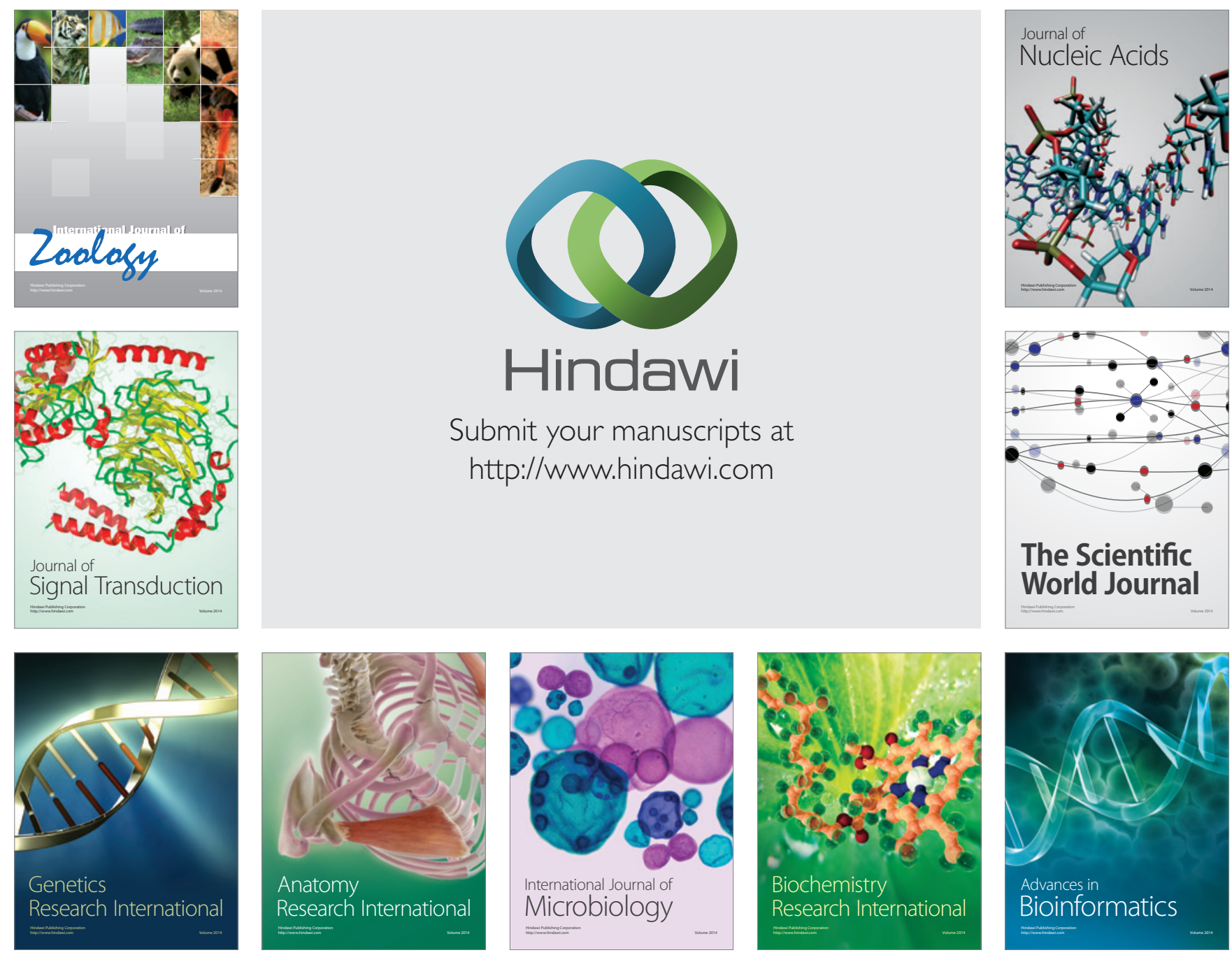

The Scientific World Journal
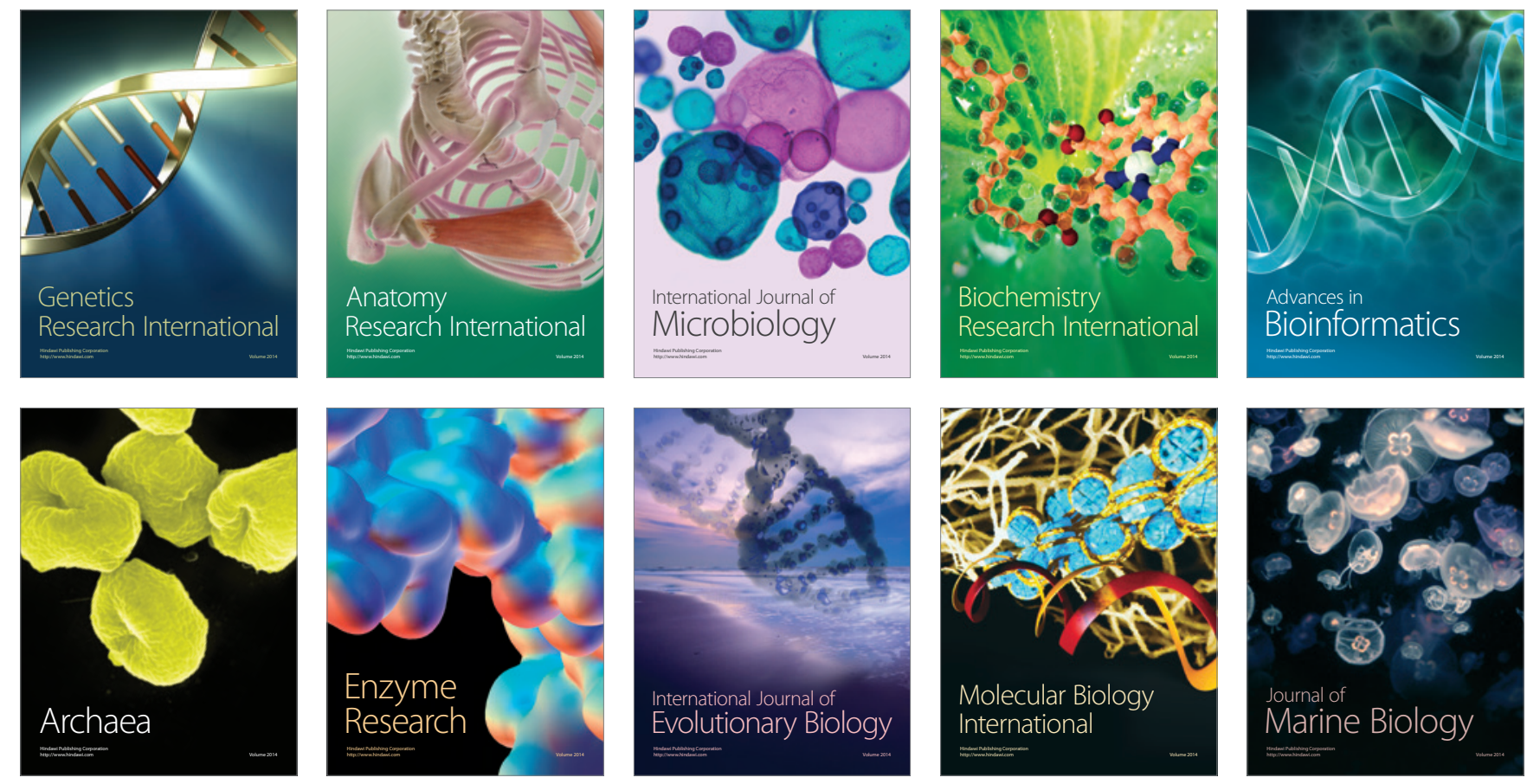